\title{
Interleukin-33-Activated Dendritic Cells Induce the Production of Thymus and Activation- Regulated Chemokine and Macrophage-Derived Chemokine
}

\author{
Masatsugu Kurokawa ${ }^{a}$ Satoshi Matsukura ${ }^{a}$ Mio Kawaguchi ${ }^{b}$ Koushi leki $^{\mathrm{a}}$ \\ Shintaro Suzuki ${ }^{a}$ Shin Watanabe ${ }^{a}$ Tetsuya Homma ${ }^{a}$ Munehiro Yamaguchi ${ }^{a}$ \\ Hiroko Takeuchia Mitsuru Adachia \\ ${ }^{a}$ Division of Respiratory Medicine and Allergology, Department of Internal Medicine, Showa University School of \\ Medicine, Tokyo, and bepartment of Respiratory Medicine, Institute of Clinical Medicine, University of Tsukuba, \\ Tsukuba, Japan
}

\section{Key Words}

Interleukin-33 · ST2 receptor · Chemokines · Dendritic cells · Mitogen-activated protein kinases

\begin{abstract}
Background: Interleukin (IL)-33, a new member of the IL-1 cytokine family, is involved in Thelper (Th)2-type responses in a wide range of diseases and is mediated by expression of the ST2 receptor in many immune cells. As the effects of IL33 on dendritic cells (DCs) remain controversial, we investigated the ability of IL-33 to modulate the functions of these cells. Methods: DCs were derived from mouse bone marrow, and the expression of the IL-33 receptor ST2 was examined by fluorescence-activated cell sorting and RT-PCR. The responses of the DCs to IL-33 were examined by RT-PCR and ELISA, and activation of mitogen-activated protein kinases (MAPKs) was determined by Western blotting. Results: ST2 ligand mRNA and protein were detectable in DCs. IL-33 induced the production of thymus and activation-regulated chemokine/CCL17 and macrophage-derived chemokine/
\end{abstract}

\begin{tabular}{ll}
\hline KARGER & $\begin{array}{l}\text { ( } 2013 \text { S. Karger AG, Basel } \\
1018-2438 / 13 / 1616-0052 \$ 38.00 / 0\end{array}$ \\
E-Mail karger@karger.com & $\begin{array}{l}\text { This is an Open Access article licensed under the terms } \\
\text { of the Creative Commons Attribution-NonCommercial- } \\
\text { www.karger.com/iaa }\end{array}$ \\
$\begin{array}{l}\text { NoDerivs 3.0 License (www.karger.com/OA-license), appli- } \\
\text { cable to the online version of the article only. Distribution } \\
\text { for non-commercial purposes only. }\end{array}$
\end{tabular}

CCL22 and the activation of extracellular signal-regulated kinase $1 / 2$, c-Jun N-terminal kinase and p38 MAPK. Conclusions: DCs respond directly to IL-33 through ST2. The interaction between IL-33 and DCs may represent a new pathway to initiate Th2-type immune responses. IL-33 and ST2 may play important roles in allergic inflammation.

Copyright $\odot 2013$ S. Karger AG, Basel

\section{Introduction}

The ST2 gene was identified originally as a gene induced by fibroblasts. Interleukin (IL)-33 is a new member of the IL-1 super-family of cytokines that is expressed mainly by structural cells, such as epithelial cells, endothelial cells and fibroblasts [1-4]. It acts as a ligand for ST2 [3], which is expressed on the cell surface of mast cells, T helper (Th) 2 cells, basophils, eosinophils and invariant natural killer T cells [5-11]. In addition, novel innate lymphoid cells that produce large quantities of Th2type cytokines in response to IL-33 have been identified
Correspondence to: Dr. Masatsugu Kurokawa

Division of Respiratory Medicine and Allergology, Department of Internal Medicine Showa University School of Medicine, 1-5-8 Hatanodai, Shinagawa-ku Tokyo 142-8666 (Japan)

E-Mail cdl94140@par.odn.ne.jp 
recently $[12,13]$. IL-1R accessory protein (IL-1RAcP) is required for IL-33-mediated signal transduction [14].

Chemokines that induce specific types of leukocyte chemotaxis play a role in the regulation of the migration and tissue accumulation of leukocytes during inflammatory and immune responses. Several lymphocyte-directed chemokines have been identified as small polypeptide molecules produced by dendritic cells (DCs), T cells, epithelial cells, endothelial cells and others [15]. Thymus and activation-regulated chemokine (TARC)/CCL17 and macrophage-derived chemokine (MDC)/CCL22 have specific chemoattractant effects on Th2-type T cells at local inflammatory sites $[16,17]$.

As the function and relationship of the IL-33 and ST2 pathways in DCs remain unclear, we investigated the ability of IL-33 to modulate the function of these cells.

\section{Materials and Methods}

\section{Animals}

Five-week-old female BALB/c mice were purchased from Sankyo Co. Inc. (Tokyo, Japan). All experiments were performed in accordance with the guidelines for animal experimentation issued by Showa University (Tokyo, Japan).

\section{Generation of Mouse Bone Marrow-Derived DCs}

DCs were generated from mouse bone marrow (BM) using an established protocol $[18,19]$. Briefly, mouse BM was obtained from the femurs and tibiae. After lysis of erythocytes, the BM cells were suspended in RPML 1640 with $10 \%$ FBS and $20 \mathrm{ng} / \mathrm{ml} \mathrm{GM-}$ CSF (R\&D Systems, Minneapolis, Minn., USA), and then incubated with $5 \% \mathrm{CO}_{2}$ at $37^{\circ} \mathrm{C}$. On days 3, 6 and 9, the medium was refreshed with GM-CSF, and nonadherent cells were harvested at day 10 . The purity of BMDCs was greater than $90 \%$. BMDCs were collected and resuspended in RPML 1640 with 10\% FBS.

\section{Detection of ST2 by Fluorescence-Activated Cell Sorting}

For fluorescence-activated cell sorting (FACS) analysis, DCs were preincubated with Fc-receptor blockers (anti-CD16/32; BD Pharmingen, San Diego, Calif., USA) for $30 \mathrm{~min}$ at $4^{\circ} \mathrm{C}$ and then stained for $30 \mathrm{~min}$ at $4^{\circ} \mathrm{C}$ with phycoerythrin(PE)-conjugated anti-CD11c (clone HL3; BD Pharmingen) and fluoroescein isothiocyanate (FITC)-conjugated rat antimouse T1/ST2 (MD Biosciences, St. Paul, Minn., USA). PE-conjugated hamster IgG1 (BD Pharmingen) and FITC-conjugated rat IgG1 (BD Pharmingen) were used as isotype controls. After washing, the DCs were resuspended, fixed and analyzed using a FACScan flow cytometer (BD Immunocytometry Systems, Mountain View, Calif., USA) with gating by a CD11c-positive forward-scatter high-cell population.

\section{Cytokine Stimulation of DCs}

To examine the effects of IL-33 on DCs, BMDCs were suspended in RPMI 1640 containing $10 \% \mathrm{FBS}$ and stimulated at $37^{\circ} \mathrm{C}$ with the medium alone or with recombinant murine IL-33 (R\&D Systems).

IL-33 Induces TARC and MDC in DCs
Reverse Transcription-Polymerase Chain Reaction

Total RNA was isolated from DCs with ISOGEN reagent (Nippon Gene Co., Ltd., Tokyo, Japan). First-strand complementary (c) DNAs were synthesized using a cDNA extraction kit (Applied Biosystems, Foster City, Calif., USA). After denaturation of the cDNA at $94^{\circ} \mathrm{C}$ for $5 \mathrm{~min}$, a polymerase chain reaction (PCR) was performed using $5 \mathrm{pmol}$ each of the forward and reverse primers, $5 \mathrm{ml}$ of cDNA, $0.6 \mathrm{U}$ of Taq polymerase (Roche Diagnostics, Basel, Switzerland) and $2.5 \mathrm{ml}$ of PCR reaction buffer $(100 \mathrm{mmol} / \mathrm{l}$ Tris$\mathrm{HCl}, 15 \mathrm{mmol} / \mathrm{l} \mathrm{MgCl} 2$ and $500 \mathrm{mmol} / \mathrm{l} \mathrm{KCl}$; Roche Diagnostics). Distilled water was added to bring the reaction volume to $25 \mathrm{ml}$. The primer sequences for ST2 ligand (ST2L) were $5^{\prime}$-TGCGTACATCATTTACCCTCGGGTC-3' (forward) and $5^{\prime}$-TCTTGTGCCACAAGAGTGAAGTAGG-3' (reverse), and for $\beta$-actin were 5'-ATCTACGAGGGCTATGCTCT-3' (forward) and $5^{\prime}$-TACTCCTGCTTGCTGATCCA-3' (reverse). The amplification reaction was performed for 33 (for ST2L) or 25 (for $\beta$-actin) cycles, with denaturation at $94^{\circ} \mathrm{C}$ for $1 \mathrm{~min}$, annealing at $60^{\circ} \mathrm{C}$ for $1 \mathrm{~min}$ and extension at $72^{\circ} \mathrm{C}$ for 1.5 min (Perkin-Elmer Cetus, Norwalk, Conn., USA). After incubation at $72^{\circ} \mathrm{C}$ for $10 \mathrm{~min}$, the PCR-amplified products were analyzed using $2 \%$ agarose gel electrophoresis and ethidium staining, followed by visualization with a UV transilluminator [20].

\section{Real-Time PCR}

TaqMan probe sets of TARC/CCL17 and MDC/CCL22 (Applied Biosystems) were used in these analyses. Each probe had a fluorescent receptor dye (FAM) linked to its $5^{\prime}$ end and a downstream quencher dye (TAMURA) linked to its $3^{\prime}$ end. We used TaqMan ribosomal RNA labeled with a fluorescent reporter dye (VIC) as an internal control. Each reaction comprised $25 \mu \mathrm{l}$ of mixture containing $2 \times$ Universal Master Mix (Applied Biosystems), primers, labeled probes and $500 \mathrm{ng}$ cDNA. Amplification conditions included 40 cycles at $95^{\circ} \mathrm{C}$ for $15 \mathrm{~s}$ and $60^{\circ} \mathrm{C}$ for $1 \mathrm{~min}$ after incubation at $95^{\circ} \mathrm{C}$ for $10 \mathrm{~min}$. The amplification and fluorescence measurements were performed during the elongation step using the ABI PRISM 7700 Sequence Detection System (Applied Biosystems). normalized against RNA Polymerase II expression; levels of specific mRNA in stimulated cells were presented as relative expression compared with control cultures using the $\mathrm{Ct}$ method. The data were analyzed using SDS 2.2 software (Applied Biosystems) and normalized against RNA. Levels of RNA in IL-33-stimulated cells were presented as relative expression compared with control cells using the $\Delta \Delta \mathrm{Ct}$ method [20].

\section{Assay of TARC and MDC in Culture Supernatants}

The levels of TARC and MDC in the culture supernatants were measured using an ELISA kit (R\&D Systems). Data are presented as picograms of TARC or MDC per $1 \times 10^{6}$ cells. The minimum detectable dose of mouse TARC and MDC was $<5 \mathrm{pg} / \mathrm{ml}$.

\section{Western Blotting}

Cells were exposed to IL-33 for 0-120 min, washed with PBS and the total protein was extracted in mammalian protein extraction reagent containing a cocktail of protease and phosphatase inhibitors (Pierce Biotechnology, Rockford, Ill., USA). The harvested lysates were then centrifuged for $10 \mathrm{~min}$ at $4^{\circ} \mathrm{C}$ to remove cellular debris, and the supernatants were collected and stored at $-80^{\circ} \mathrm{C}$. Protein concentration was measured using the BCA protein assay reagent kit (Pierce Biotechnology). For Western blot- 


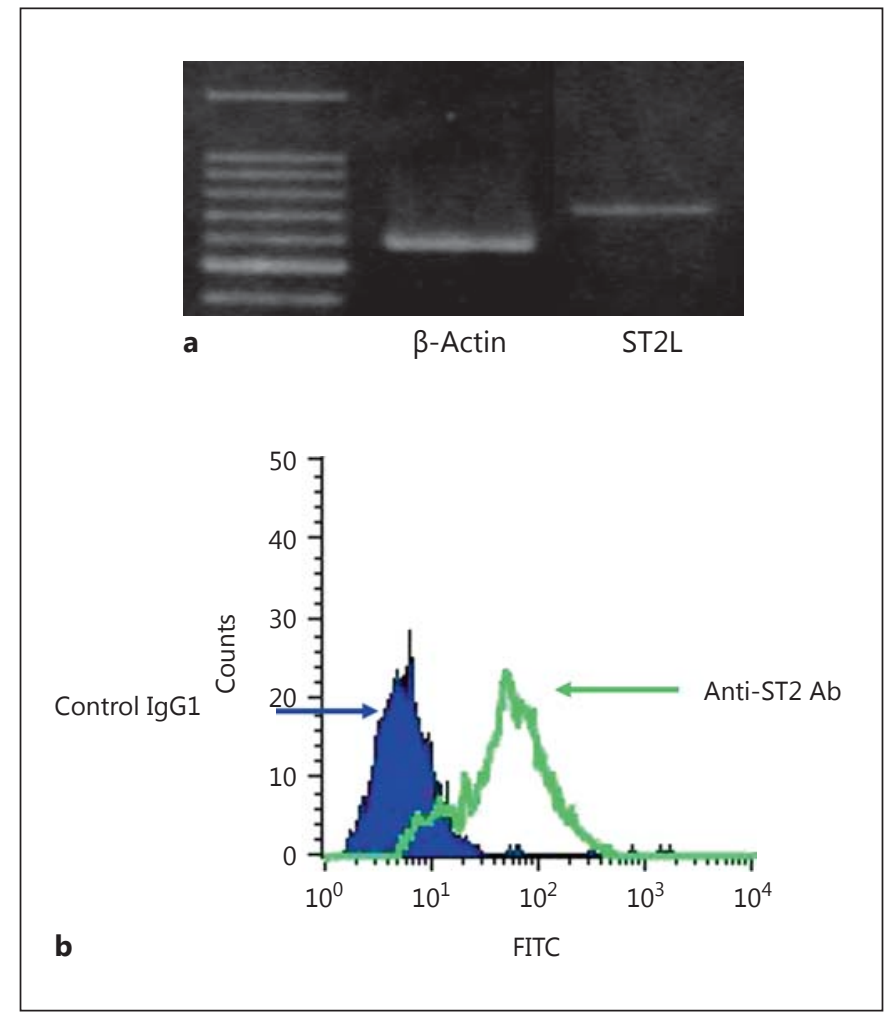

Fig. 1. DCs express ST2 mRNA and ST2 protein. a Total RNA was purified from DCs, and ST2L mRNA expression was examined by RT-PCR. Representative results of RT-PCR were visualized on a $2 \%$ electrophoresis gel. b FACS analyses of purified DCs showing the surface expression of ST2 protein. The control antibody was rat IgG1 isotype control (dark blue area) and anti-ST2 (green line). Data are representative of 3 independent experiments ( 4 mice per group).

ting, $20 \mu \mathrm{g}$ of protein from each sample was separated electrophoretically on 4-20\% Tris-glycine gradient gels (Novex, San Diego, Calif., USA) and then transferred to a nitrocellulose membrane (Schleicher \& Schuell, Dassel, Germany). The blots were blocked with $5 \%$ non-fat milk powder in TBST ( $50 \mathrm{mM}$ Tris, $0.15 \mathrm{M} \mathrm{NaCl}$ and $0.05 \%$ Tween 20 ) at room temperature for $1 \mathrm{~h}$, washed 3 times in TBST buffer, followed by incubation at $4{ }^{\circ} \mathrm{C}$ overnight with primary antibody [phosphorylated extracellular signal-regulated kinase (ERK)1/2, c-Jun N-terminal kinase (JNK), p38 mitogenactivated protein kinase (MAPK) and total ERK1/2, JNK and p38 MAPK 1:1,000 (Cell Signaling Technology, Danvers, Mass., USA)]. The membranes were then incubated at room temperature for $1 \mathrm{~h}$ with secondary antibody, HRP-conjugated anti-rabbit IgG antibody 1:3,000 (Cell Signaling Technology). After extensive washing with TBST, we added a chemiluminescent substrate (ECL Western blot detection system, Amersham, Biosciences) and subjected the membrane to autoradiography. The reaction products were detected using an enhanced chemiluminescence detection system.
Statistical Analysis

The results were expressed as means \pm SE. Significant differences in the results were detected using the Tukey test. Differences were considered significant at $\mathrm{p}<0.05$.

\section{Results}

\section{Expression of the IL-33 Receptor ST2 in DCs}

We first examined whether DCs express ST2 mRNA and protein. Using RT-PCR, we detected ST2L mRNA in BMDCs (fig. 1a).

A FACScan was also used to study the expression of surface ST2 protein and showed that this protein was indeed expressed on the surface of DCs (fig. 1b).

\section{IL-33-Activated DCs Induce Expression of TARC and $M D C$}

As ST2 protein was detectable on the surface of DCs on FACScans, we investigated whether IL-33 could induce any functional responses in these cells. The concentrations of the chemokines TARC/CCL17 and MDC/ CCL22 were measured after the DCs had been stimulated with IL-33. These studies demonstrated that IL-33-stimulated DCs showed significant enhancement of TARC/ CCL17 and MDC/CCL22 mRNA levels compared with unstimulated DCs. The extent of this upregulation was dose-dependent (fig. 2a, b).

To evaluate if the production of these proteins accompanied the expression of these mRNA, we determined the amount of TARC/CCL17 and MDC/CCL22 protein in the supernatants of DCs. TARC/CCL17 and MDC/ CCL22 production was expressed as $\mathrm{pg} / 1 \times 10^{6}$ cells. Stimulation with IL-33 showed significant enhancement of TARC/CCL17 and MDC/CCL22 levels compared with unstimulated DCs. Stimulation with IL-33 caused a dosedependent upregulation of TARC/CCL17 and MDC/ CCL22 protein expression (fig. 2c, d).

\section{IL-33 Promotes Phosphorylation of ERK1/2, JNK and p38 MAPK in DCs}

To determine the signaling pathways involved in IL33-induced expression of chemokines in DCs, untreated or IL-33-stimulated cells were lysed at various time points, and Western blotting was performed using antibodies against members of the MAPK family, including ERK1/2, JNK and p38 MAPK. Western blotting of lysed, untreated or IL-33-stimulated cells demonstrated that the phosphorylation of ERK1/2, JNK and p38 MAPK was initiated after 5-15 min of treatment with IL-33 and returned to baseline levels at $120 \mathrm{~min}$ (fig. $3 \mathrm{a}-\mathrm{c}$ ).
Kurokawa et al. 

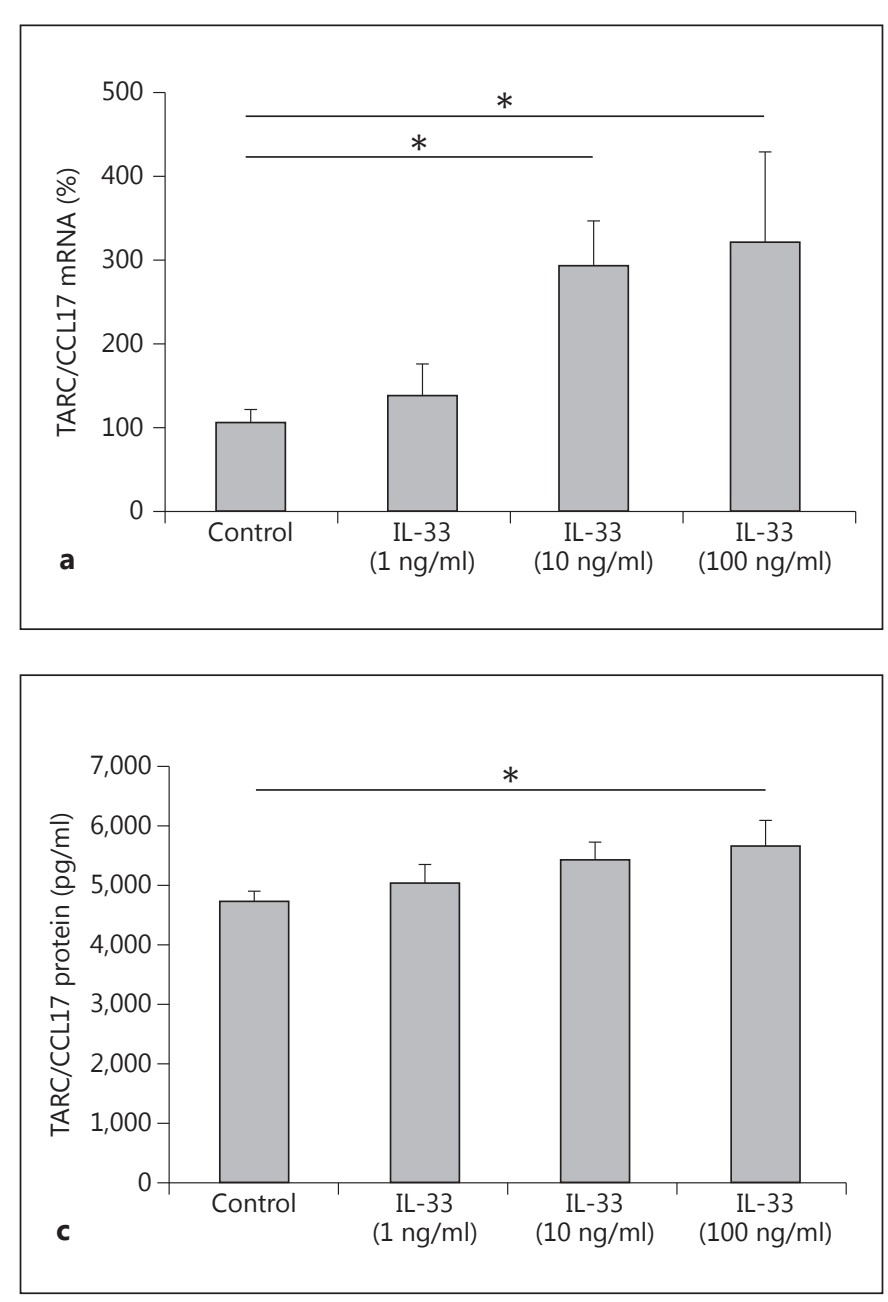

Fig. 2. TARC/CCL17 and MDC/CCL22 expression in DCs. Expression of TARC/CCL17 (a) and MDC/CCL22 (b) mRNA in DCs was determined by real-time PCR at $4 \mathrm{~h}$ after IL-33 stimulation. TARC/CCL17 (c) and MDC/CCL22 (d) protein concentrations in

\section{Discussion}

DCs are the major antigen-presenting cells and play a pivotal role in immune responses [21]. It has been shown previously that although DCs contain ST2 protein, this has not been detected on their surface [22]. Our study suggests that DCs express ST2 constitutively and are activated by IL-33 through ST2. We are not certain, however, whether or not this discrepancy may be attributable to technical differences in our experimental approach.

Treatment of DCs with IL-33 upregulates cell-surface expression of MHC class II molecules and the costimulatory molecules CD86 [22], CD40 and CD80, and also increases production of proinflammatory cytokines and che-
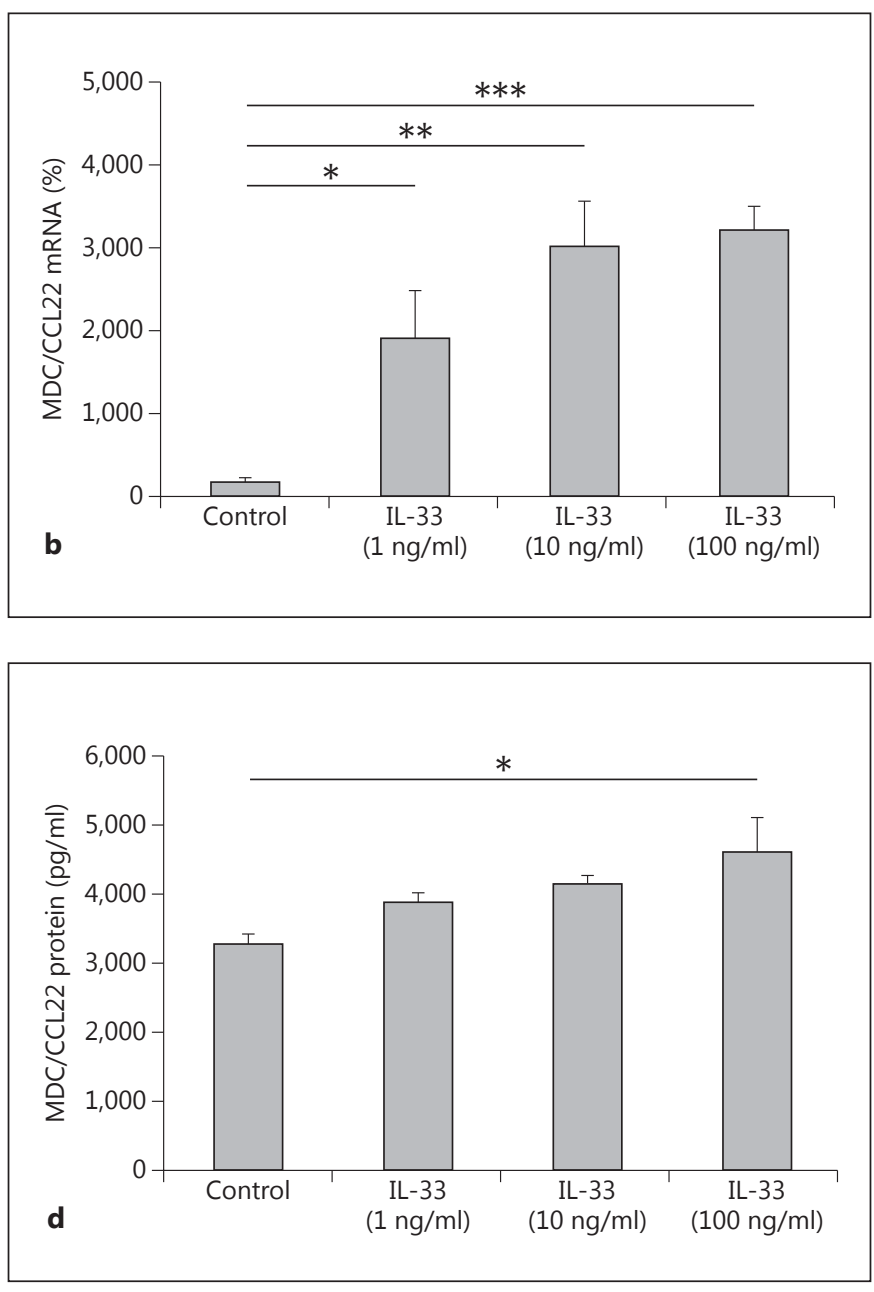

supernatants were also measured by ELISA at $48 \mathrm{~h}$ with IL-33 stimulation. Each sample was analyzed in duplicate. Data are representative of 3 independent experiments ( 8 mice per group). ${ }^{*} \mathrm{p}<0.05$, ${ }^{* *} \mathrm{p}<0.01,{ }^{* * *} \mathrm{p}<0.001$.

mokines [23]. In this study, we demonstrated that IL-33 caused potent activation of DCs, resulting in the production of the chemokines TARC/CCL17 and MDC/CCL22. This production by DCs is related to Th2-mediated allergic inflammation. We were able to detect TARC/CCL17 and MDC/CCL22 protein in the supernatants of nontreated DCs. But, we are not certain whether these results are attributable to technical differences. IL-33 appears to be expressed by epithelial cells, fibroblasts and smooth muscle cells. Thymic stromal lymphopoietin (TSLP) is also expressed by epithelial cells. TSLP causes potent activation of DCs and induces the production of the Th2-attracting chemokines, TARC/CCL17 and MDC/CCL22 [24]. IL-33 may therefore be another tissue-derived factor that activates 


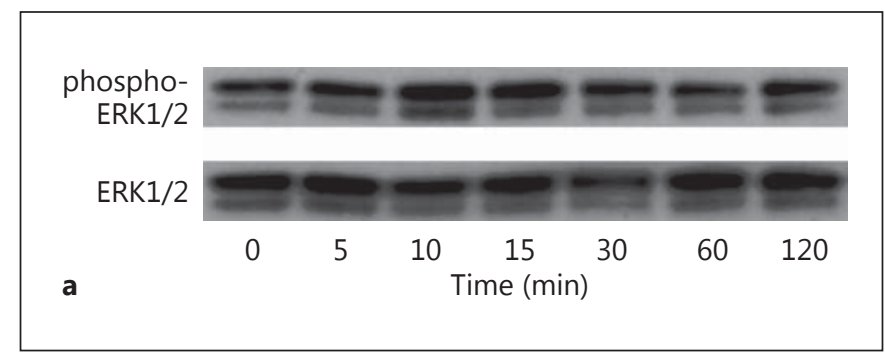

Fig. 3. IL-33-induced phosphorylation of MAPKs in DCs. Wholecell lysates were examined for the expression of phospho-ERK1/2, ERK1/2 (a), phospho-JNK, JNK (b) as well as phospho-p38 MAPK and p38 MAPK (c) at the time points indicated following stimulation with IL-33 (100 ng/ml). Data are representative of 3 independent experiments ( 4 mice per group).

DCs and profoundly affects the production of Th2-type chemokines, similar to that observed with TSLP.

Next, we evaluated the signaling pathways involved in the IL-33 responses in DCs. IL-33 signals by interacting with the receptor complex consisting of membrane-bound ST2 and IL-1RAcP, resulting in the activation of NF- $\mathrm{KB}$ and MAPK [3]. This pathway induces the production of several cytokines and chemokines. The production of TARC/CCL17 in response to IL-33 is mediated by an NF$\kappa B$-independent MAPK-dependent pathway [25]. IL-33/ ST2 signaling pathways have been reported in several cells, although they vary in the different cells. IL-33/ST2 signaling pathways therefore remain poorly understood in DCs.

IL-33 is known to activate ERK1/2, JNK and p38 MAPK signaling cascades in mast cells [3], basophils [10], macrophages [26] and fibroblasts [27]. IL-33 also activates ERK1/2 and p38 MAPK in eosinophils [10] and microvascular endothelial cells, but only ERK1/2 in bronchial epithelial cells [28]. We demonstrated that IL-33 induced the activation of ERK, JNK and p38 MAPK in DCs, and also showed that these cells had distinct differences in requirements for MAPK in the IL-33-mediated signaling pathway. These mechanistic differences between DCs and other cells in their IL-33-mediated signaling pathways need to be elucidated in further studies.

In summary, this study defines a role for IL-33/ST2 in type 2 immunity as an important enhancer for the development of activated DCs by the production of TARC and MDC. IL-33 and ST2 may play important roles in Th2 allergic inflammation.
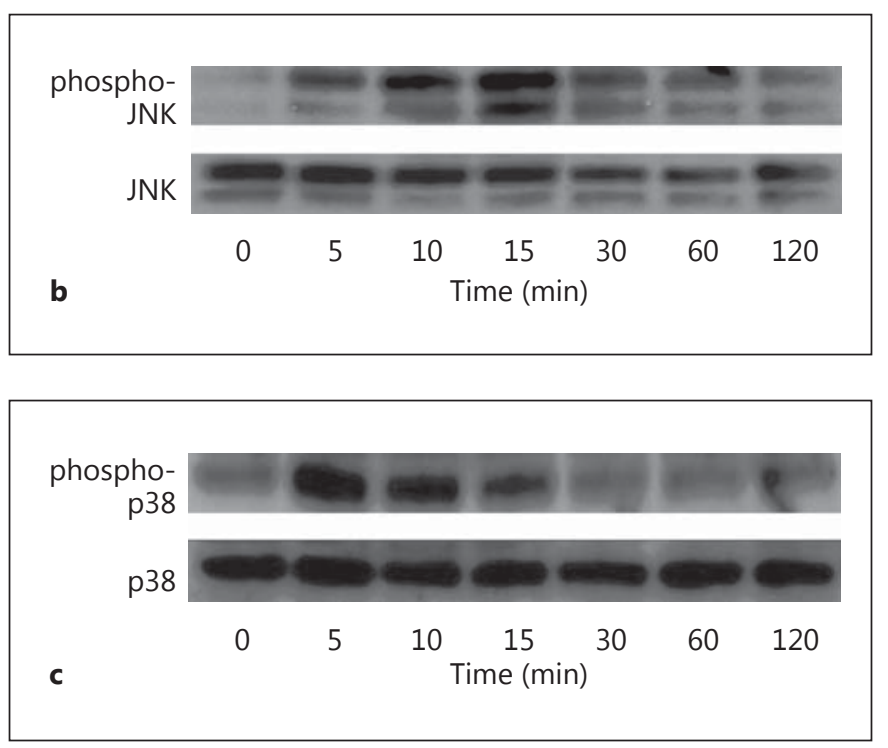

\section{Acknowledgement}

This work was supported by a grant from Showa Medical Foundation, Tokyo, Japan.

\section{Disclosure Statement}

The authors declare that no financial or other conflict of interest exists in relation to the content of this article.

References specific cDNA from $\mathrm{BALB} / \mathrm{c}-3 \mathrm{~T} 3$ cells is highly similar to the extra-cellular portion of mouse interleukin 1 receptor. FEBS Lett 1989; 258:301-304

2 Yanagisawa K, Takagi T, Tsukamoto T, Tetsuka T, Tominaga S: Presence of a novel primary response gene ST2L, encoding a product highly similar to the interleukin 1 receptor type 1. FEBS Lett 1993;318:83-87.

- 3 Schmitz J, Owyang A, Oldham E, Song Y, Murphy E, McClanahan TK, Zurawski G, Moshrefi M, Qin J, Li X, Gorman DM, Bazan JF, Kastelein RA: IL-33, an interleukin-1-like cytokine that signals via the IL-1 receptor-related protein ST2 and induces T helper type 2-associated cytokines. Immunity 2005;23: 479-490.

4 Moussion C, Ortega N, Girard JP: The IL-1like cytokine IL-33 is constitutively expressed in the nucleus of endothelial cells and epithelial cells in vivo; a novel 'alarmin'? PLoS ONE 2008; $3: \mathrm{e} 3331$
Kurokawa et al. 
5 Moritz DR, Rodewald HR, Gheyselinck J, Klemenz R: The IL-1 receptor-related T 1 antigen is expressed on immature and mature mast cells and on fetal blood mast cell progenitors. J Immunol 1998;161:4866-4874.

-6 Allakhverdi Z, Smith DE, Comeau MR and Delespesse G: The ST2 ligand IL-33 potently activates and drives maturation of human mast cells. J Immunol 2007;179:2051-2054.

7 Lohning M, Stroehmann A, CoyleAJ, Grogan JL, Lin S, Gutierrez-Ramos JC, Levinson D, Radbruch A, Kamradt T: T1/ST2 is preferentially expressed on murine Th2 cells, independent of interleukin 4, interleukin5, and interleukin 10, and important for Th2 effector function. Proc Natl Acad Sci USA 1998;95: 6930-6935.

-8 Smithgall MD, Comeau MR, Yoon BR, Kaufman D, Armitage R, Smith DE: IL-33 amplifies both Th1- and Th2-type responses through its activity on human basophils, allergen reactive Th2 cells, iNKY and NK cells. Int Immunol 2008;20:1019-1030.

-9 Suzukawa M, Iikura M, Koketsu R, Nagase H, Tamura C, Komiya A, Nakae S, Matsushima K, Ohta K, Yamamoto K, Yamaguchi M: An IL-1 cytokine member, IL-33, induces human basophil activation via its ST2 receptor. J Immunol 2008;181:5981-5989.

10 Pecaric-Petkovic T, Didichenko SA, Kaempfer S Spiegl N, Dahinden CA: Human basophils and eosinophils are the direct target leukocytes of the novel IL-1 family member IL33. Blood 2009;113:1526-1534.

$\checkmark 11$ Cherry WB, Yoon J, Bartmes KR, Iijima K, Kita H: A novel IL-1 family cytokine, IL-33, potently activates human eosinophils. J Allergy Clin Immunol 2008;121:1484-1490.

-12 Moro K, Yamada T, Tanabe M, Takeuchi T, Ikawa T, Kawamoto H, Furusawa J, Ohtani M, Fujii H, Koyasu S: Innate production of Th2 cytokines by adipose tissue-associated cKit(+)Sca1(+) lymphoid cells. Nature 2010; 463:540-544.
3 Neill DR, Wong SH, Bellosi A, Flynn RJ, Daly M, Langford TK, Bucks C, Kane CM, Fallon PG, Pannell R, Jolin HE, McKenzie AN: Nuocytes represent a new innate effector leukocyte that mediates type- 2 immunity. Nature 2010;464:1367-1370.

14 Chackerian AA, Oldham ER, Murphy EE, Schmiz J, Pflanz S, Kastelein RA: IL-1 receptor accessory protein and ST2 comprise the IL-33 receptor complex. J Immunol 2007;179: 2551-2555.

15 Baggiolini M: Chemokines and leukocyte traffic. Nature 1998;392:565-568.

16 Yoshie O, Imai T, Nomiyama H: Novel lymphocyte-specific CC chemokines and their receptors J Biol Chem 1997;62:634-644.

17 Imai T, Nagira M, Takagi S, Kakizaki M, Nishimura M, Wang J, Gray PW, Matsushima $\mathrm{K}$, Yoshie O: Selective recruitment of CCR4bearing Th2 cells toward antigen-presenting cells by CC chemokines thymus and activation-regulated chemokine and macrophagederived chemokine. Int Immunol 1999;11: 81-88.

18 Inaba K, Inaba M, Romani N, Aya H, Deguchi M, Ikehara S, Muramatsu S: Steinman RM: Generation of large numbers of dendritic cells from mouse bone marrow cultures supplemented with granulocyte/macrophage colony-stimulating factor. J Exp Med 1992;176: 1693-1702.

19 Kurokawa M, Konno S, Takahashi A, Plunkett B, Rittling SR, Matsui Y, Kon Shigeyuki, Morimoto J, Uede T, Matsukura S, Kokubu F, Adachi M, Nishimuna M, Huang SK: Regulatory role of DC-derived osteopontin in systemic allergen sensitization. Eur J Immunol 2009;39:3323-3330.

20 Kurokawa M, Kokubu F, Mastsukura S, Kawaguchi M, Ieki K, Suzuki S, Odaka M, Watanabe S, Takeuchi H, Akabane T, Asano $\mathrm{K}$, Iwase M, Honma I, Adachi M: Effect of corticosteroid on the expression of thymus and activation-regulated chemokine in a murine model of allergic asthma. Int Arch Allergy Immunol 2005;137(suppl 1):60-68.
21 Banchereau J, Steinman RM: Dendritic cells and the control of immunity. Nature 1998; 392:245-252.

22 Rank MA, Kobayashi T, Kozaki H, Bartemes KR, Squilance DL, Kita H: IL-33-activated dendritic cells induce an atypical Th2-type response. J Allergy Clin Immunol 2009;123: 1047-1054.

23 Besnard AG, Togbe D, Guillou N, Erard F, Quesniaux V, Ryffel B: IL-33-activated dendritic cells are critical for allergic airway inflammation. Eur J Immunol 2011;41:16751686.

24 Soumelis V, Reche PA, Kanzler H, Yuan W, Edward G, Homey B, Gilliet M, Ho S, Antonenko S, Lauerma A, Smith K, Gorman D, Zurawski S, Abrams J, Menon S, McClanahan T, de Wall-Malefyt R, Bazan F, Kastelein RA, Liu YJ: Human epithelial cells trigger dendritic cell trigger dendritic cell mediated allergic inflammation by producing TSLP. Nat Immunol 2002;3:673-680.

25 Kurowska-Stolarska M, Kewin P, Murphy G, Russo RC, Stolarski B, Garcia CC, Komai-Koma M, Pitman N, Li Y, Niedbala W, McKenzie AN, Teixeira MM, Liew FY, Xu D: IL-33 induced antigen-specific IL-5+ T cell and promotes allergic-induced airway inflammation independent of IL-4. J Immunol 2008;181: 4780-4790.

26 Ohto-Ozaki H, Kuroiwa K, Mato N, Matsuyama $\mathrm{Y}$, Hayakawa $\mathrm{M}$, Tamemoto $\mathrm{H}$, Tominaga S: Characterization of ST2 transgenic mice with resistance to IL-33. Eur J Immunol 2010;40:2632-2642.

-27 Funakoshi-Tago M, Tago K, Hayakawa M, Tominaga S, Ohshio T, Sonoda Y, Kasahara $\mathrm{T}$ : TRAF is a critical signal transducer in IL-33 signaling pathway. Cellular Signalling 2008; 20:1679-1686.

28 Yagami A, Orihara K, Morita H, Futamura K, Hashimoto N, Matsumoto K, Saito H, Matsuda A: IL-33 mediates inflammatory responses in human lung tissue cells. J Immunol 2010; $185: 5743-5750$. 